\title{
On Fusarium Wilt of Spinach and its Causal Fungus
}

\author{
Takashi NAIKI* and Masakazu KANO**
}

内記 隆*・加納正和**：ホウレンソウ萎ちょう病とその病原菌について

In Gifu Prefecture, continuous commercial production of spinach (Spinacia oleracea L.) from May to October has been developed in mountainous and cool summer districts in and around Takayama City where assigned as administratively designated vegetable-production area. In this area, a simple vinyl house equipped with watering system, as a new cultural method, has already become popular to control some diseases and physiological disorders caused by unfavorable climatic conditions such as temperature variation and heavy and long-lasting rain. For the last four years, a serious disease of spinach has occurred in several vinyl house croppings in the summer and early fall production areas, and seems to increase its severity year after year. The symptoms were characterized by wilting, root rot and discoloration of the vascular system of the plants.

Isolations of pathogens from infected plants in various parts of these areas revealed that Fusarium oxysporum was the most prevalent fungus, followed by Rhizoctonia solani and some other species. Spinach inoculated with $F$. oxysporum showed the same symptoms as observed in the field, and the same fungus was reisolated from interior of diseased roots. None of the other fungi isolated from infected plants caused the same symptoms on spinach as shown in the field. Spinach wilt caused by Fusarium was first described by Hungerford ${ }^{1)}$ in U. S. A.. Though Okuda and Furuta ${ }^{2}$ isolated $F$. oxysporum from wilted spinach in Tottori Prefecture and $\mathrm{Matuo}^{3}$ ) suggested the occurrence of $F$. oxysporum f. sp. spinaciae in Japan, the formal description of Fusarium wilt of spinach and its pathogen has not been reported in Japan. In this paper, symptoms of Fusarium wilt of spinach and the characters of the causal fungus are described.

Fusarium wilt of spinach in vinyl house cropping was most prevalent in the summer and early fall production. That the disease was so much serious in the above season may have been due to the higher soil temperature. The frequency of disease occurrence was differed among fields and it was greater in open field cropping than in vinyl house cropping. Infected plants in the seedling stage of 2-3 weeks after seeding wilted and died. In the mature stage, wilting of the outer leaves was the first symptom of the disease followed by yellowing of them. These symptoms spreaded progressively to young inner ones and consequently the infected plant died. The main root and lateral roots of the infected plant were blackish brown (Fig. 1). The black lesions on the main root frequently surrounded the basal part of the lateral root, indicating that infection began in this part and progressed

* Laboratory of Plant Pathology, Faculty of Agriculture, Gifu University, Kagamigahara, Gifu 504, Japan. 岐阜大学農学部

** Gifu Agricultural Experimental Station, Gifu 501-11, Japan. 岐阜県農業試験場

1. Hungerford, C. W. (1923). Phytopathology $13: 205-209$.

2. Okuda, J. and Furuta, C. (1964). Ann. Phytopath. Soc. Japan 29 : 89 (Abstr.).

3. Matuo, T. (1962) In The guide of soil borne disease (Hori, M. et al. eds.). Nihon Syokubutsu Boeki Kyokai, Tokyo. pp. 57-67. 
to the main root. There were few lateral roots of the older infected plant and the main root frequently rotted off (Fig. 2). The vascular system of the root and the petiole of the infected plant was discolored (Fig. 3). Hyphae and microconidia of the fungus were observed in the vascular system (Fig. 4).

The total number of 510 isolates of $F$. oxysporum from diseased root tissues in 6 different fields were obtained in September, 1976. Most of them (82.2\%) were pathogenic to spinach seedlings. The figures of the fungus are shown in Fig. 5 . Microconidia abundant, hyaline, elliptic, long elliptic or ovoid, $3.8-12.5 \times 2.5-5.0 \mu \mathrm{m}$, formed in aggregation on short, simple phialides arising laterally on the hyphae. Macroconidia sparse, hyaline, sickle formed, slightly curved, 1-4 septate, formed phialidic. The 3 septate spore in the range $23.8-42.5 \times 3.8-5.0 \mu \mathrm{m}$ is most commomly found. Chlamydospores abundant, spheric or elliptic, smooth and rough walled, light brown, single or in chain, terminal or intercalary, found mostly on hyphae. The fungus grew well on ordinary media. The temperature optimum for hyphal growth lies between 25 and $30 \mathrm{C}$. These characters and the range of conidial size of this fungus agree with the original description of $F$. oxysporum f. sp. spinaciae ${ }^{1,4)}$.

Three monoconidial isolates of pathogenic $F$. oxysporum were grown on potatodextrose agar and used in the inoculation test. Sterilized spinach field soil was infested with spores $\left(2 \times 10^{4} / \mathrm{g}\right.$ of dry soil $)$ of the respective isolates. After thorough mixing, test plants of species and spinach cultivars were seeded in the infested soil in $56 \times 32 \times 12 \mathrm{~cm}$ plastic boxes and/or in $450 \mathrm{ml}$ glazed pots. Three replicates of each treatment were placed in a growth cabinet kept at $25 \mathrm{C}$. About 30-35 days after seeding, there appeared no external symptoms of wilt on any of test plants except for sugar beet, chard and spinach (Table 1). Among plants belonging to the family Chenopodiaceae, spinach seedlings showed the most severe wilt within 2-3 weeks after seeding (Figs. 6 and 8), but sugar beet and chard were relatively

Table 1. Pathogenicity of spinach Fusarium to various plants

\begin{tabular}{|c|c|c|c|c|c|}
\hline \multirow{3}{*}{ Test plant (Cultivar) } & \multirow{3}{*}{$\begin{array}{l}\text { Number of } \\
\text { seeds }\end{array}$} & \multicolumn{4}{|c|}{$\%$ Wilted (Diseased) } \\
\hline & & \multicolumn{3}{|c|}{ Isolate from spinach } & \multirow{2}{*}{ Controla) } \\
\hline & & $\mathrm{F}-40$ & $\mathbf{F}-60$ & F-107 & \\
\hline Lettuce (Great lake) & 100 & 0 & 0 & 0 & 0 \\
\hline Watermelon (Ibuki) & 30 & 0 & 0 & 0 & 0 \\
\hline Melon (Cantaloup) & 30 & 0 & 0 & 0 & 0 \\
\hline Cucumber (Tachibana) & 30 & 0 & 0 & 0 & 0 \\
\hline Tomato (Oogata fukuju) & 50 & 0 & 0 & 0 & 0 \\
\hline Eggplant (Senriyo 2) & 50 & 0 & 0 & 0 & 0 \\
\hline Kidney bean (Kintoki) & 30 & 0 & 0 & 0 & 0 \\
\hline Soybean (Mejiro-daizu) & 30 & 0 & 0 & 0 & 0 \\
\hline Pea (Akabana-suzunari) & 30 & 0 & 0 & 0 & 0 \\
\hline Onion (Nagaoka OL) & 50 & 0 & 0 & 0 & 0 \\
\hline Cabbage (Nagaoka 1) & 40 & 0 & 0 & 0 & 0 \\
\hline Radish (Harumaki-minowase) & 40 & 0 & 0 & 0 & 0 \\
\hline Sugar beet (Kawe megamono) & 60 & 6.7 & 11.7 & 5.0 & 0 \\
\hline Chard (Shiroguki Ooba) & 60 & 8.3 & 5.0 & 3.3 & 0 \\
\hline Goosefoot & 100 & 0 & 0 & 0 & 0 \\
\hline Spinach (Fukamidori) & 60 & 100 & 98.3 & 100 & 0 \\
\hline
\end{tabular}

a) No infested soil. 
resistant to the fungus and showed only 5.0-11.7\% and $3.3-8.3 \%$ disease, respectively. Goosefoot (Chenopodium amaranticolor) showed no symptoms during experimental period. Seedlings of all test plants which exhibited no external symptoms were harvested at the end of experimental period and their root and hypocotyl discoloration were examined. Hypocotyl discoloration of seedlings $(>30 \%)$ was found only in sugar beet and chard. In another inoculation test, the root of 4 weeks old plants of spinach was dipped into heavey spore suspension of the fungus and transplanted into sterilized soil. The inoculated plant showed the external symptoms of wilting and yellowing of the outer leaves 3 weeks after inoculation (Fig. 7). The main root and lateral roots of the infected plant were blackish brown (Fig.9), and the vascular system of the root was discolored (Fig. 10). Thus artificially inoculated seedlings and mature plants of spinach showed the characteristic symptoms of the disease which had been noted in the field. These symptoms were similar to those described as Fusarium wilt of spinach ${ }^{1,5)}$. On the other hand, there were differences in the percentage of wilting of seedlings among 6 cultivars (Table 2). Nobel which has been developed from S. oleracea var. grabra was most susceptible to the fungus followed by Fukamidori, and more than

Table 2. Pathogenicity of 3 isolates of Fusarium oxysporum to seedlings of some spinach cultivars

\begin{tabular}{l|c|c|c|c}
\hline \multirow{2}{*}{ Cultivar } & \multicolumn{3}{|c|}{$\%$ Wilted (Diseased) } \\
\cline { 2 - 5 } & \multicolumn{3}{|c|}{ Isolate from spinach } & \multirow{2}{*}{ Mean $^{\text {b) }}$} \\
\cline { 2 - 5 } & F-40 & F-67 & F-107 & 71.1 \\
\hline Jiromaru & 78.0 & 67.9 & 67.5 & 71.7 \\
Wakakusa & 85.5 & 87.1 & 81.1 & 76.9 \\
Hôyô & 80.9 & 68.7 & 74.3 & 80.4 \\
New Asia & 84.4 & 82.4 & 98.3 & 99.4 \\
Fukamidori & 100 & 100 & 100 & 100 \\
Nobel & 100 & 100 & 82.2 & \\
\hline Mean of isolatec & 88.1 & 84.4 & & \\
\hline
\end{tabular}

a) Three replicates using 15-20 plants per treatment.

$\begin{array}{ll}\text { b) } \operatorname{LSD} 0.05=28.0 & \text { c) } \operatorname{LSD} 0.05=39.8\end{array}$

$98 \%$ of test seedlings wilted within 21 days after seeding. Conversely, Jiromaru originated from S. olercicea var. spinosa was relatively resistant. Among 3 Fusarium isolates, there were no appreciable differences in pathogenicity on seedlings of test plants. After the disease had been found in Takayama City, our survey revealed its presence in numerous parts of Gifu Prefecture, where spinach was generally grown in open fields from the late fall to winter. The causal fungus of this disease is believed to be widely distributed in spinach cultivated areas in Japan.

We are indebted to professor T. Matuo, Shinshu University, Professor T. Ui, Hokkaido University, and Professor H. Ikegami, Gifu University for their helpful suggestion and critical reading of the manuscript.

(Received April 22, 1977)

4. Snyder, W. C. and Hansen, H. N. (1940). Am. J. Bot. $27: 64-67$.

5. Cook, H. T., Nugent, T. J., Parris, G. K. and Porter, R. P. (1947). Virginia Truck Exp. Sta. Bull. 110 : 1810-1820. 

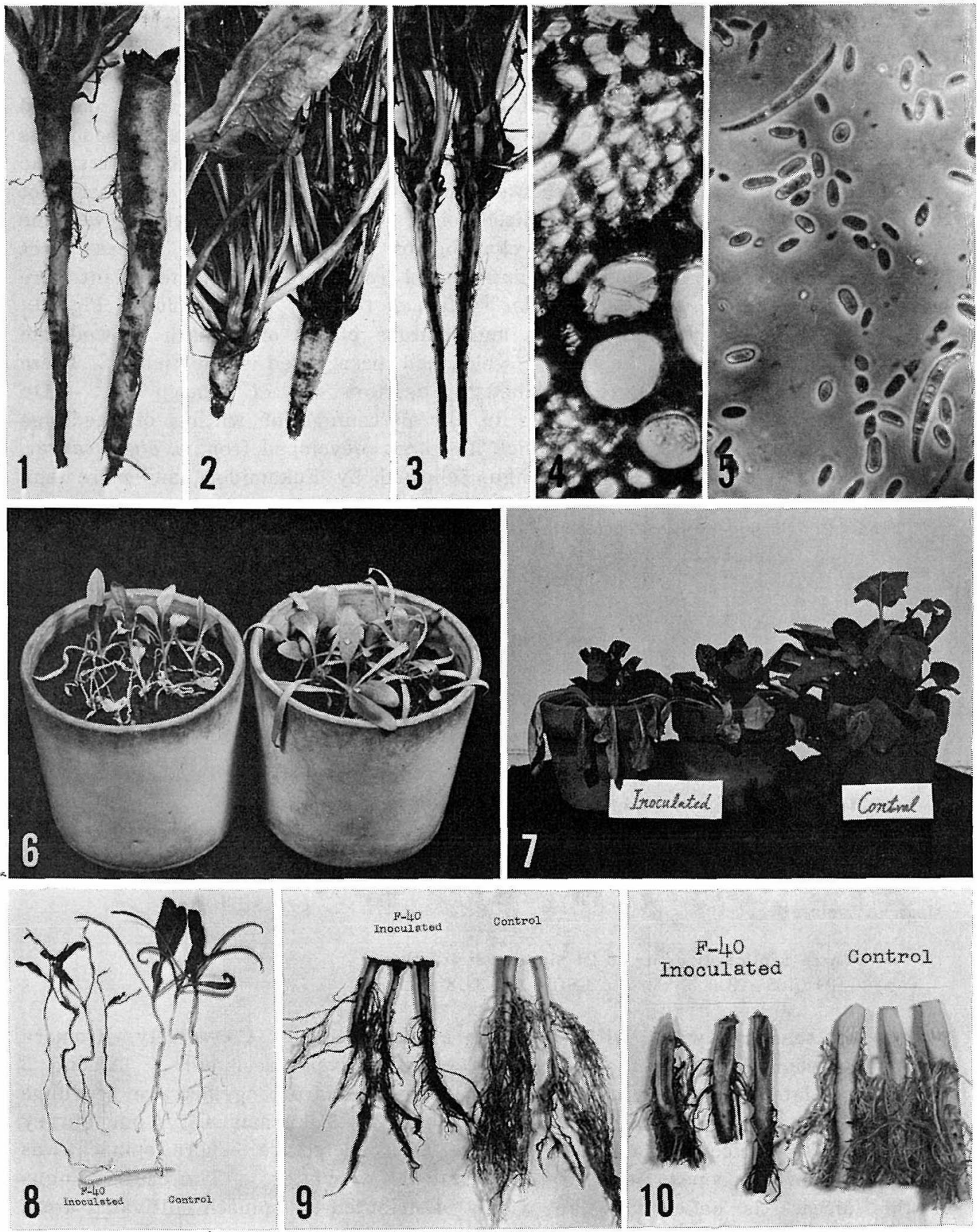

Explanation of plate

Fig. 1. Black lesions on main roots surrounded the basal part of lateral roots.

Fig. 2. Main roots completely rotted off.

Fig. 3. Diseased roots showing discolored vascular system.

Fig. 4. Hyphae of the fungus observed in vascular system.

Fig. 5. Microconidia and macroconidia of spinach Fusarium (Isolate F-40).

Figs. 6. and 7. Symptoms of wilt of artificially infected spinach seedlings and mature plants, respectively.

Figs. 8. and 9. Spinach seedlings infected in the early and advanced stages of growth

respectively; showing discolored root systems.

Fig. 10. Discoloration of vascular system of infected main roots. 